\title{
PERAN PEMBERDAYAAN PEREMPUAN DI ZAMAN SEKARANG
}

\author{
Titis Muthiana Taqwim \\ Email: 2010128220023@ulm.ac.id \\ Program Studi Pendidikan IPS Fakultas Keguruan dan Ilmu Pendidikan \\ Universitas Lambung Mangkurat \\ Banjarmasin
}

\begin{abstract}
Abstrak
Saat ini peran perempuan menjadi materi yang dibicarakan oleh Negaranegaradi dunia. Arus globalisasi menjadikan peran perempuan menjadi topik yang menarik. Kehadiran peran perempuan semakin meminta penambahan kedudukan dan posisi yang memadai baik dalam pemerintahan maupun di masyarakat, sehingga kedudukan kaum perempuan patut untuk diperhitungkan.Peran perempuan dalam pembangunan seringkali diragukan karena dianggap tidak layak dan tidak mampu. Perempuan dan laki-laki memiliki kesetaraan, sehingga perempuan dan laki-laki mempunyai kesempatan, akses serta peluang yang sama sebagai sumber daya pembangunan. Kesetaraan merupakan target yang harus dicapai dalam tujuan pembangunan nasional jangka menengah dan jangka panjang. Perempuan tidak hanya menjadi pengguna hasil pembangunan, namun juga ikut berperan melaksanakan dan berpartisipasi di segenap aspek pembangunan bangsa. Usaha-usaha pemerintah untuk meningkatkan kemampuan perempuan dengan cara pemberdayaan, yang mengandung arti meningkatkan kualitas dan peran perempuan disegala bidang pembanguan.
\end{abstract}

\section{PENDAHULUAN}

Pembangunan adalah suatu isu penting yang tak pernah berhenti dibicarakan baik itu oleh negara miskin, negara yang sedang berkembang ataupun negara maju. Meskipun konteks yangdibicarakan ataupun cara yang digunakan untuk melaksanakan berbeda beda pada setiap negara. Pembangunan pada hakekatnya adalah suatu upaya terus menerus,yang bersifat sistematis dan terencana secara sebagian ataupun keseluruhan komponen bangsa untuk mengubah suatu keadaan menjadi keadaan yang lebih baik dengan memanfaatkan segala sumber daya yang ada dengantujuan untuk meningkatkan kesejahteraan dan meningkatkan kualitas hidup manusia danmasyarakat disuatu negara, demikian juga yang dilakukan pemerintah Indonesia. 
Pembangunan pada hakekatnya bertujuan untuk memperbaiki dan meningkatkan kualitas hidup manusia yang dilakukan secara terencana dan berkesinambungan. Sebagai sebuah proses peningkatan kualitas hidup manusia, pembangunan adalah konteks dimana kebijakan beroperasi. Untuk mencapai tujuan tersebut, maka pembangunan perlu diimplementasikan kedalam berbagai program pembangunanyang dapat secara langsung menyentuh masyarakat.

Perkembangan ilmu pengetahuan dan teknologi membawa dampak pada peran perempuan yang semakin kompleks. Era sekarang ditandai dengan pesatnya perkembangan teknologi informasi dan komunikasi (TIK). Melalui perkembangan teknologi informasi dan komunikasi ini pengambilan, penyebaran dan penyajian informasi dapat dilakukan secara cepat dan akurat. Pengaruh positif perkembangan teknologi informasi dan komunikasi terhadap segala aspek kehidupan manusia seperti mempermudah melakukan komunikasi dan mendapatkan informasi yang semakin luas,dapat mendorong pertumbuhan ekonomi serta dapat mengoptimalkan efisiensi tenaga kerja. perempuan memiliki peran yang sangat strategis, sebagai ibu rumah tangga dan sekaligus juga memiliki peran dalam masyarakat. . Pengakuan terhadap kesetaraan antara perempuan dan laki-laki sudah menjadi issu global, namun kesenjangan akses dan penguasaan teknologi informasi dan komunikasi antara perempuan dan laki-laki masih cukup besar. Kesetaraan gender menjadi sorotan dalam rangka memajukan peran perempuan dalam pembangunan.

\section{Pembangunan: Suatu Konsep}

Pembangunan secara umum dapat diartikan sebagai usaha untuk meningkatkan kehidupan masyarakat kearah yang lebih baik. Ndraha (1985) menyatakan bahwa pembangunan (development) adalah segala upaya untuk mewujudkan perubahan sosial, besar-besaran dari suatu keadaan yang lebih baik. Keraf dalam Susanto, (2003) mengatakan bahwa ada tiga prinsip utama menuju keberhasilan pembangunan berkelanjutan, yaitu: pertama, prinsip demokrasi, prinsip ini menjamin agar pembangunan dilaksanakan sebagai perwujudan kehendak bersama seluruh rakyat. Kedua, prinsip keadilan, prinsip ini menjamin bahwa semua orang dan kelompok masyarakat memperoleh peluang yang sama untuk ikut dalam proses pembangunan dan kegiatan-kegiatan produktif serta ikut dalam menikmati hasil pembangunan. Ketiga, prinsip berkelanjutan, prinsip ini mengharuskan kita untuk merancang agenda pembangunan dalam dimensi visioner, melihat dampak pembangunan baik positif maupun negatif dalam segala aspeknya tidak hanya dalam dimensi jangka pendek.Pelaksanaan programpembangunan lebih bersifat mendorong agar masyarakat lebih banyak berperan, sehingga unsur pemberdayaan serta kemandirian masyarakat diharapkan dapat melahirkan model alternatif program pembangunan berdasarkan musyawarah bersama yang mampu memberikan jaminan bagi penyelesaian permasalahan sosial yang dihadapi. 


\section{Peran Perempuan dalam masyarakat}

Partisipasi perempuan saat ini tidak hanya sekedar menuntut persamaan hak, tetapi juga menyatakan fungsinya dan mempunyai arti bagi pembangunan dalam masyarakat Indonesia. Pada kabinet kerja era 2014-2019 kementerian pemberdayaan perempuan dan perlindungan anak (KPPPA) diperkuat dengan Peraturan Presiden no. 59 tahun 2015, Peran perempuan dalam pembangunan dapat dimaksimalkan dengan meningkatkan kualitas hidup terutama akses terhadap fasilitas pendidikan, kesehatan dan hukum. Posisi, peran dan aktivitas perempuan Indonesia didalam dunia publik semakin meningkat dalam ukurannya sendiri dari waktu ke waktu dalam sejarah Indonesia.Hubeis (1985) mengatakan, perempuan memegang peranan strategis yakni sebagai pekerja rumah tangga (mengatur rumah, membesarkan dan mengasuh anak), berperan sebagai pekerja transisi (bekerja dalambidang usaha keluarga) dan sebagai pekerja diluar rumah tangga sebagai perempuan karier. Sesungguhnya perempuan memiliki potensi luar biasa yang dapat dimanfaatkan untuk kemajuan bangsa Kemajuan dalam bidang ekonomi dan pendidikan mempengaruhi perempuan mengambil peran transisi yakni sebagai tenaga kerja, anggota masyarakat dan manusia pembangunan (Wibowo, 2011), untuk menunjukan eksistensi dirinya. Perempuan berkualitas mampu menempatkan dirinya dalam peran yang sangat penting baik sebagai ibu dalam mendidik generasi masa depan, maupun dalam ranah publik termasuk di era sekarang

\section{Upaya Pembangunan Pemberdayaan perempuan dalam pembangunan}

Pemberdayaan masyarakat dalam konteks community develoment bearti pertumbuhan kuasaan dan wewenanag bertindak pada masyarakat untk mengatasi masalah mereka sendiri (Chamberss: 1995).Dalam hal ini, perencanaan responsive gender sebagai perencanaan yang dilakukan dengan memeasukkan perbedaan-perbedaan pengalaman,aspirasi,kebutuhan dan permasalahan perempuan dan laki-laki.proses penyusunannya. Wujud penumbuhan kekuasaan dan wewenang tersebut dengan memberi kesempatan bagi masyarakat untuk merencanakan hingga menikmati program pembangunan yang ditentukan oleh mereka sendiri.

Upaya pemberdayaan masyarakat tidak membedakan siapapun dalam berpartisipasi di berbagai hal. Laki-laki maupun perempuan mempunyai hak yang sama. Diskriminasi gender pada dasarnya dapat terjadi baik pada laki-laki maupun perempuan, namun secara agregat diskriminasi gender cenderung lebih banyak dialami perempuan. Bentuk-bentuk ketidakadilan gender meliputi marjinalisasi, subordinasi, pandangan stereotype, kekerasan 
serta beban kerja ganda perempuan. Terdapat tiga pendekatan dalam memberdayakan masyarakat termasuk perempuan, antara lain: (1) pendekatan yang terarah, artinya pemberdayaan masyarakat harus terarah yakni berpihak kepada seluruh masyarakat termasuk perempuan; (2) pendekatan kelompok, artinya secara bersama-sama untuk memudahkan pemecahan masalah yang dihadapi, dan (3) pendekatan pendampingan, artinya selama proses pembentukan dan penyelenggaraan kelompok masyarakat perlu didampingi oleh pendamping yang professional sebagai fasilitator, komunikator, dan dinamisator terhadap kelompok untuk mempercepat tercapainya kemandirian.

Pada dasarnya pemberdayaan masyarakat merupakan suatu proses dimana masyarakat khususnya yang kurang memiliki akses kepada sumber daya pembangunan didorong untuk meningkatkan kemandirian dalam mengembangkan perikehidupan mereka termasuk kaum perempuan.

\section{SIMPULAN}

Diambil suatu kesimpulan bahwa pemberdayaan perempuan dalam pembangunan haruslah didorong dan ditumbuhkan dengan menciptakan suasana dan kondisi yang baik secara intern maupun ekstern yang dapat memungkinkan perempuan untuk turut serta dan berpartisipasi secara aktif dalam setiap tahapan pembangunan. Partisipasi yang dimaksudkan adalah partisipasi dalam seluruh proses dan tahapan pembangunan mulai dari proses perencanaan, pelaksanaan, pengawasan sampai kepada pelestarian dalam Program Pengembangan pembangunan. Kaum perempuan sebagai pendidik generasi penerus harus mampu berbuat banyak, agar menjadi generasi yang mampu bersaing di era global, beretika, dan membanggakan, baik bagi diri sendiri, keluarga, masyarakat, bangsa dan negara. 


\section{REFERENSI}

Dewi, Y. S. (2011). PERAN PEREMPUAN DALAM PEMBANGUNAN BERKELANJUTAN WOMEN IN SUSTAINABLE DEVELPMENT. Jurnal Ilmiah

Pendidikan Lingkungan dan Pembangunan, 12(2), 61-64.

Foilyani, F. H. (2009). PEMBERDAYAAN PEREMPUAN PERDESAAN DALAM

PEMBANGUNAN (Studi Kasus Perempuan Di Desa Samboja Kuala, Kecamatan Samboja, Kabupaten Kutai Kertanegara). WACANA, Jurnal Sosial dan Humaniora, 12(3), 592-608.

Indah, I. (2013). Peran-peran perempuan dalam masyarakat. Academica, 5(2).

Indarti, S. H. (2019). PERAN PEREMPUAN DALAM PEMBANGUNAN

MASYARAKAT. The Indonesian Journal of Public Administration (IJPA), 5(1).

Parawansa, K. I. (2003). Pemberdayaan perempuan dalam pembangunan

berkelanjutan. Bali, hlm, 1-15.

Prasetyawati, N. (2018). Perspektif Gender dalam Pembangunan Nasional Indonesia. IPTEK Journal of Proceedings Series, (5), 53-60.

Probosiwi, R. (2015). Perempuan Dan Perannya Dalam Pembangunan Kesejahteraan Sosial (Women and Its Role on Social Welfare Development). Jurnal Natapraja: Kajian Ilmu Administrasi Negara, 3(1).

Rinawati, R. (2004). Partisipasi wanita dalam pembangunan. MIMBAR: Jurnal Sosial dan Pembangunan, 20(3), 387-405.

Sadjuri, K. (2014). Pemberdayaan Perempuan dalam Pembangunan Berbasis

Partisipasi. MUWAZAH: Jurnal Kajian Gender, 2(2).

Sadjuri, K. (2014). Pemberdayaan Perempuan dalam Pembangunan Berbasis

Partisipasi. MUWAZAH: Jurnal Kajian Gender, 2(2).

Sofiani, T. (2013). Membuka ruang partisipasi perempuan dalam pembangunan. MUWAZAH: Jurnal Kajian Gender, 1(1).

Zamroni, M. (2013). Perempuan dalam kajian komunikasi politik dan gender. Jurnal Dakwah, 14(1), 103-132. 